\title{
Michał Sajewicz
}

\author{
Maria Curie-Skłodowska University in Lublin (Poland) \\ Email: msajewicz@poczta.umcs.lublin.pl \\ ORCID: https://orcid.org/0000-0001-8468-3010
}

\section{Significant Contribution to the Research on the Urbanonymity of the Polish- -Eastern Slavic Linguistic and Cultural Borderland}

\author{
Monika Famielec, Урбанонимы города Бреста XX века [Urbanonyms of the \\ city of Brest of the XX century], Bydgoszcz: Wydawnictwo Uniwersytetu Kazimie- \\ rza Wielkiego, 2018, 292 pp.
}

$\mathrm{I}^{\mathrm{t}}$ n 2018, the monograph of Dr. Monika Famielec entitled Urbanonyms of the city of Brest of the XX century was published by the Kazimierz Wielki University in Bydgoszcz publishing house. The author of the monograph works at the Department of Onomastics and Russian Language History at the Institute of Modern Languages and Applied Linguistics of the Kazimierz Wielki University in Bydgoszcz. The dissertation describes the urbanonymy of the $20^{\text {th }}$ century Brest, a city located in western Belarus, where the Bug and Mukhavets rivers meet, in the immediate vicinity of the Polish border.

The main purpose of the monograph reviewed herein was to determine the distinctive nature of Brest urbanonymy. A city on the Polish-Belarusian-Ukrainian border, it has been strongly influenced by several Slavic cultures and languages from the very beginning of its existence. This is reflected both in the onomastic and toponymous characteristics of the city, i.e. in the personal names of the city inhabitants and in the city's urban toponymy.

Famielec's monograph is an attempt to determine the unique features of Brest's urbanonymy as well as to trace the development of city names under the influence of non-linguistic factors. The author tried to answer one of the key questions: Do the $20^{\text {th }}$-century city names of Brest reflect its character as a city on the border? If so, to what extent?

The monograph analyses not only contemporary city names (hodonyms) but also urbanonymous systems characteristic of other periods. These were distinguished according to the city's changing nationality over the centuries, which always entailed significant changes in the names of streets, squares and other urban facilities. The following description draws a distinction between the following periods of the $20^{\text {th }}$ century Brest: 
- 1900-1919 (Russian Empire);

- 1919-1939 (Second Polish Republic);

- 1939-1941 (BSSR);

- 1941-1944 (Third German Reich);

- 1944-1991 (BSRR);

- 1991-2000 (Republic of Belarus).

The analysis of the modern urban toponymy of Brest allowed for determining its current specifics. The analysis of historical urbanonyms facilitated the tracking of the dynamics of development and changes the names underwent in the past.

The research involved the use of two methods: descriptive and comparative.

The broad resource base used in the monograph can be evaluated positively. The author extracted a rich onomastic material from various archival sources, cartographic studies, tourist guides, lists of Brest streets, both published in print and posted on the websites of various institutions.

The monograph follows a proper, coherent and well-designed structure. It consists of an introduction, seven chapters, an ending, bibliography, two annexes, an index of city names analysed, as well as abstracts in Polish, Belarusian and English.

The introduction (pp. 7-33) specifies the subject and purpose of the study. It also justifies the choice of the subject and the object of the study, presents the research methodology, describes the existing investigations into the field of Slavonic urbanonymy, and discusses the structure of the dissertation.

It could be argued that including only brief information about the theoretical and methodological foundations of the study in the introduction might have been more expedient. A detailed discussion of theoretical and terminological issues could be included in a new chapter, entitled e.g. The theoretical basis of the research.

Given the variety of concepts and terms used in particular subdomains of onomastics, there is a need to address several important issues related to this field of linguistics, but only in a succinct manner. The new chapter should rather deal more extensively with urbanonyms, which are the main object of research of the reviewed dissertation. It would be indispensable to address the following issues:

- urbanonymy within the scope of onomastics;

- object of research in the field of urbanonymy;

- the notion of urbanonymy;

- alternative terms: urban terminology, city toponymy, urban toponymy, etc.

- the origin and development of studies on urban toponymy.

- classification of urbanonyms (according to inter alia A. Supierańska, A. Miezienko, M. Gorbaniewski, K. Handke).

- formation of urban terminology (M. Gorbaniewski et al.).

The classification system put forward by K. Handke (1992) has been repeatedly and successfully employed by numerous researchers of urban terminology. Based upon a fundamental division into urbanonyms originating from appellative and proprial names, this classification make it possible to easily distinguish the most productive 
ways of onymic nomination ${ }^{1}$. The reader may, however, have the impression that the author is more inclined to the classification scheme developed by the Belarussian researcher A. M. Miezienko (1991).

The first chapter of the dissertation (pp. 35-59), devoted mainly to historical issues The city of Brest and the cities of modern Belarus is too extensive. Not all the issues it raises are directly related to the main objective of the dissertation. It would be therefore reasonable to shorten this chapter by removing unnecessary or too detailed historical passages. The author could introduce new content instead, regarding the sociological, religious, cultural and linguistic circumstances of the area examined, which seems necessary in the study of border areas such as Brest. Due to the lack of clearly articulated information of this type, it is difficult to absorb the content presented in the monograph. For instance, the reader must know that Brest, although a Belarusian city, is located in an area where the Ukrainian dialect is used more often than the Ukrainian-Belarusian transitional dialect (Dejna, 1996, pp. 13-20). Furthermore, this area is inhabited mostly by people who have not formed a national identity, the so-called Poleshuks. This is conducive to the search for new national, religious and cultural identities. The Brest region is known in Belarus for the activity of the New Evangelical churches (including Jehovan's Witnesses, Baptists, Pentecostals) as well as other religious associations. Brest is also one of the most Russified voblast capitals in Belarus. One of the reasons for this situation is that numerous soldiers and officers, mostly Russian, who served in the Brest garrison settle in this city for economic reasons.

The main part of the monograph are chapters 2-7 (pp. 35-230) devoted to the semantic and structural analysis of urbanonymity in $20^{\text {th }}$ century Brest, cf.:

Chapter 2. The city of Brest of Brest-Litovsk (1900-1919);

Chapter 3. The city of Brest-on-Bug (1919-1939);

Chapter 4. The city of Brest (1939-1941);

Chapter 5. The city of Brest (1941-1944);

Chapter 6. The city of Brest (1944-1991);

Chapter 7. The city of Brest (1991-2000).

The time frame adopted by the author for the first two periods, cf. The city of Brest of Brest-Litovsk (1900-1919), and The city of Brest of Brest-on-Bug (1919-1939) may raise some doubt. 1919 seems to be a somewhat arbitrary date. The nationality of Brest was not defined at that time, with German troops still present in the city. On February 9, 1919 the city was recaptured by the Polish voluntary military formation the Vilnius Self-Defence unit commanded by Jerzy Dąbrowski. For these reasons, the choice of the time limits for both periods seem justified.

K. Handke claims: Such division allows for discerning nomination types of broad and flexible content. At the same time, it allows for creating comparisons, partly referring to the types of meaning defined in other onomastic systems, toponomy in particular. Depending on the specific nature of the given data, it is possible to further define and modify this division (Handke, 1992, p. 62). 
The second chapter of the monograph (pp. 61-70) was devoted to the analysis of the Brest urbanonyms used throughout the years 1900-1919, i.e. during the tsarist rule, before Poland gained independence. Famielec makes a detailed semantic and structural analysis of the collected anthropological material (53 names). Regrettably, the author did not compare the urbanonyms functioning at that time with those from before the partitions of the Polish-Lithuanian Commonwealth. This would elicit the oldest layer of the terminology examined. When describing an urbanonym, the scholar does not always provide the date when the name was formed. It is difficult to tell whether the name was adopted from the pre-partition period (either expressed in the Cyrillic script or translated), or perhaps changed or only created after the partitions. The author seems to attach less importance to comparative research and the use of statistical methods, which is not entirely appropriate. It is the chronological list of street names in Brest that would demonstrate the real nature of the government during particular periods of the city's development, as well as the system of values and authorities at the time. This, however, would require a slightly different methodology for the description of the material collected. It would have to consider the changes in the names of urban objects which occurred over a given period in comparison to the previous period to a much greater extent. It is also important to determine the reasons why the names of streets and squares were changed in particular periods.

In the third chapter of the monograph (pp. 71-98), Famielec discusses the urbanonymy of Brest in 1919-1939. The semantic and structural analysis encompasses 175 urbanonyms (it is an increase by 122 names compared to the previous period). After Brest became a part of the Second Polish Republic, the names of its streets and squares changed radically. Many old urbanonyms were replaced with new ones, which referred to the Polish reality, history and culture. The research showed some continuity preserved in certain street and alley names. This applies in particular to urbanonyms based on appellativa. For instance, some cultural, configuration, natural and metaphorical names have been preserved, but in the Polish alphabet. In some cases, their form changed. It should be noted in the description that a particular name had been kept, whereas in cases of a changed name, the description should state the reasons for the change. The system of references to the previous period adopted by the author, although effective, is used inconsistently and selectively. It does not always accurately reflect the continuation and change of urban terminology.

The fourth chapter (pp. 99-122) presents the urban toponymy of Brest in 19391941. At that time, the city was a part of the BSRR. This does not mean, however, that the new names of streets and squares referred to the Belarusian realities, history and culture in any way. There were no Belarusian poets or writers, leaders of uprisings, outstanding printers or publishers, or scholars and artists among the patrons of the Brest streets. Instead, there are numerous politicians, military commanders, poets, writers and artists of Russian origin. The previous street and square names reflecting the history and culture of Poland, 'gave way to new names corresponding to the ideology of Soviet power' (Famielec, 2018, p. 99). Cf. some street names of that time: 
Barikadnaya (Barricade), Deputatskaya (Deputy), Internacyonalnaya (International), Kommunisticheskaya (Communist), Komsomolskaya (Komsomol), Kooperativnaya (Cooperative), Krasnaya (Red), Krasnogvardeyskaya (Red Guards), Krasnoznamennaya (Red Banner), Krasnoflotskaya (Red Navy), Partisanskaya (Partisan), Pionerskaya (Pioneer), Proletarskaya (Proletarian), Rabochaya (Workers), Sovetskaya (Soviet), Trudovaya (Labor). It was a very radical change of Brest street names, introduced by the Russians primarily for ideological reasons. Only a few street names which had been used in the inter-war period or before the First World War remained in Brest. The author attempts to present both the continuation of the Brest toponymy (names adopted from previous periods) as well as the changes it underwent by referring to the previous periods examined. However, the way she does it is not always consistent or transparent. It would be worth to point out, if possible, the reasons for the preservation of the few traditional names of Brest streets in the description. Perhaps it could be possible to establish certain patterns in names changes so far and in naming new streets.

The author devoted Chapter 5 of monograph (pp. 123-145) to the hodonims found in Brest during the German occupation (1941-1944). There are several remarkable statements she makes regarding the city's toponymy in Brest. The author states, among others, that the occupier:

- revoke the names of streets and squares that were in force in Brest in 1939-1941;

- restored the Polish terminology used in the years 1919-1939 (either with the Polish spelling retained or with some Polish consonants rendered in accordance with German spelling);

- changed a small number of street names, mainly high streets, to German ones in order to commemorate Nazi leaders and the heroism of German soldiers;

Changes to the names of Brest streets and squares made by the German occupier were relatively minor compared to the changes introduced in 1939-1941. This remark of the author is perfectly correct.

It is impossible to provide a reliable description of the urban toponymy of Brest during the German occupation without making a thorough comparison with the hodonyms used in the city in the interwar years (1919-1939), and in some cases also in the previous periods (1900-1919). Therefore, it was necessary to include numerous references in the text to show both the continuity and variability of the Brest urbanonymy under the German occupation. However, the cross-reference system does not always clearly illustrate these phenomena.

In the sixth chapter (pp. 147-199), the author focused on the description of Brest urbanonymy in the post-war years, when the city was part of the BSRR (1944-1991). As Monika Famielec rightly notes, the city returned to the names used in 1939-1941. Some street names changed in the meantime, whereas the other, especially in residential areas created after the war, were given new names. This process calls for an extensive and detailed analysis. It would be also suitable to trace the process of 'nationalizing' the Brest urbanonymy, i.e. the streets and squares which were given names referring to the Belarusian history and culture. Although this process ensued to a very 
limited extent at that time, it would be worth including it the monograph. It is simply insufficient to state that the street names commemorating such outstanding Belarusian artists and cultural activists as Janka Kupała, Jakub Kołas and Francisk Skaryna appeared in Brest for the first time in 1944-1991.

The seventh chapter (pp. 201-230) calls for a different description methodology. It contains a dictionary of urbanonyms used in Brest in 1991-2000, when the city was part of the independent Belarusian state (Republic of Belarus). The vast majority of Brest urbanonyms used today functioned already in the years 1944-1991, and some of them did also in previous periods. However, circa 80 new street names appeared during this period. Therefore, two important questions should have been posed:

- were there any new tendencies in the Brest urbanonymy in 1991-2000 in the context of different political conditions, i.e. independence of Belarus?;

- was the phenomenon of Belarusianisation of the Brest urbanonymy system observed during this period?

The author answers these questions indirectly and to some degree, but does not present this information explicitly. This is would be appropriate at this point, given the new trends in respect of naming streets and squares in Brest. The author notes that:

Заметным результатом проводившейся в первой половине 90 -х гг. белорусизации были наименования, восходящие к белорусскому языку (Волошковая, Житняя, Журавиная, Суничная, Сябровская улица) ${ }^{2}$ (Famielec, 2018, p. 238).

However, in the period described

Существенного обновления брестской годонимии с целью придания ей народного характера не замечено ${ }^{3}$ (Famielec, 2018, p. 238).

It is worth noting that the Brest urbanonyms did not undergo a full-fledged 'nationalization' process throughout the years 1991-2000. This is apparent from the scarce number of Belarusian patrons of modern Brest streets. Among them are some outstanding Belarusian artists and cultural activists: the aforementioned Janka Kupała, Jakub Kołas and Francysk Skaryna, as well as Maksim Bahdanowicz, who was commemorated after Belarus gained independence.

The list of contemporary Brest urbanonyms contained in Chapter 7 should definitely contain references to the previous period (1944-1991), and possibly to the earlier periods as well. However, the author is not consistent in this practice, which in

2 A notable result of the Belarusization carried out in the first half of the 90s were the names that go back to the Belarusian language (Voloshkovaya, Zhitnyaya, Zhuravinaya, Sunichnaya, Syabrovskaya street).

3 A significant renewal of the Brest godonymy in order to give it a national character has not been noticed. 
some cases makes it difficult for the reader to determine which street names have survived from the earliest times to the present day, and which ones have undergone changes at different stages of the city's history.

The monograph ends (pp. 231-240) in a somewhat laconic manner. The summary contains a large amount of information already presented in the particular chapters of the paper. The author draws several interesting conclusions from the research, based on rich and stimulating material. Not all of these conclusions, however, were articulated explicitly in the final part of the monograph.

The monograph is supplemented with concise abstracts in Polish, Belarusian and English (pp. 285-292). It seems fitting to consider attaching a summary in the Ukrainian language as well, given the city's location on the Polish-Belarusian-Ukrainian border. Moreover, the Brest region has always been within the area of influence of the Ukrainian language (Dejna, 1996, pp. 13-20; Sajewicz, 1993, pp. 254-263).

As to the literature used in the dissertation, there are no major shortcomings to remark upon. The attached bibliography is rich, containing about 230 papers, not only in the field of onomastics. These are mostly studies conducted by Polish, Belarusian and Russian researchers. However, there are no publications of Ukrainian authors, which is surprising in a monograph devoted to the urbanonymy of Brest, a city located on the Polish-Belarusian-Ukrainian border in terms of language and culture. The author also does not refer to Western European research in the field of urbanonymy.

I have no serious reservations about the formal side of the monograph. Both footnotes and bibliography are formatted correctly, and so is the entire text of the dissertation. However, the author could have left less space between the text and footnotes.

In respect of the language of the monograph, the author generally used Russian language correctly. Although Polish authors writing texts in Russian often make linguistic (lexical and stylistic) errors, these are rare in the reviewed work.

The author's delivery is reader-friendly and easy to understand, even though the monograph deals with complex issues in the field of historical and contemporary urbanonymy. The book will thus probably find many readers outside the linguist environment. It may prove interesting for regionalists keen on the history and culture of Brest - a city so close to the Polish border.

The monograph is undeniably a work of great merit. Its primary attributes include a rich resource base as well as a skilful and thorough analysis of the collected anthroponymous material. It belongs to the valuable studies of anthroponymy of the Polish-Belarusian-Ukrainian linguistic borderland (see e.g. Denda, 2012 ${ }^{4}$ ). In a way, the monograph summarises the author's years of research on the urbanonymy of border areas and fills the gap in the existing literature in the field of urbanonymy on the Polish-Eastern Slavic border. The author exhibits excellent competence both in the theoretical and the empirical part of the dissertation.

4 See other publications of M.H. Denda on the urbanonymy of the Polish-East Slavic borderlands, fragments of which were quoted in the monograph reviewed. 
The review does contain several critical remarks. The author of the monograph entitled Urbanonyms of the city of Brest of the XX century, Monika Famielec, has drawn several contentious conclusions. Most of the criticism raised in the review is of purely polemical nature and does not change my generally positive assessment of the author's work. I would like to emphasise that she clearly put tremendous effort into the study of the subject. Her competent and comprehensive analysis of the complex and thus far insufficiently examined onomastic material collected at the Polish-East Slavic language and cultural border is an important scientific achievement and greatly contributes to the research on the urbanonymy of the Polish-Belarusian-Ukrainian borderland. Moreover, it definitely goes beyond this sphere of research, combining both linguistic and historical-cultural aspects. I am convinced that the monograph of Monika Famielec will be welcomed not only among onomasters, but also historians, sociologists and culture experts.

Translated into English by Marek Robak-Sobolewski

\section{References}

Dejna, Karol. (1976). Językowa przynależność gwar brzesko-pińskich. In: K. Bajor (ed.), Języki i literatury wschodniostowiańskie (pp. 13-20). Łódź: Wydawnictwo Uniwersytetu Łódzkiego.

Denda, Monika, Honorata. (2012). Urbanonimia pogranicza polsko-ukraińskiego (na materiale nazw ulic i placów Przemyśla i Lwowa). Maszynopis rozprawy doktorskiej przygotowanej pod kierunkiem prof. dr. hab. Michała Sajewicza.

Famielec, Monika. (2018). Urbanonimy goroda Bresta XX veka. Bydgoszcz: Wydawnictwo Uniwersytetu Kazimierza Wielkiego. [Famielec, Monika. (2018). Урбанонимы города Бреста ХХ века. Bydgoszcz: Wydawnictwo Uniwersytetu Kazimierza Wielkiego].

Handke, Kwiryna. (1992). Polskie nazewnictwo miejskie. Warszawa: Slawistyczny Ośrodek Wydawniczy.

Sajewicz, Michał. (1993). O ustalaniu przynależności językowej gwar peryferyjnych (na przykładzie gwar poleskich). Rozprawy Slawistyczne, 6, pp. 254-263.

Mezenko, Anna. (1991). Urbanonimiâ Belorussii. Minsk: Universitetskoe. [Мезенко, Анна. (1991). Урбанонимия Белоруссии. Минск: Университетское]. 